Brit. J. vener. Dis. (1961), 37, 219.

\title{
FLAGYL IN THE ORAL TREATMENT OF TRICHOMONAL VAGINITIS*
}

\author{
BY \\ LOUIS G. FEO \\ From the Department of Urology, Jefferson Medical College Hospital, Philadelphia
}

Several reports may be found in the literature on the trichomonicidal properties of derivatives of Azomycin (Nakamura, 1955; Horie, 1956; Cosar and Julou, 1959). Among this group, 1-(2-hydroxyethyl)-2-methyl-5-nitroimidazole (Flagyl) was found to possess a high activity and a very low toxicity in experimentally-infected mice (Cosar and Julou, 1959). These results were confirmed by Durel, Roiron, Siboulet, and Borel $(1959,1960)$, and the studies were extended to include a clinical trial of the drug in trichomonal infections. The results of the trial were encouraging and the effect was attributed to the trichomonicidal property of the serum and urine. The last-named study has been followed by others, and the success rate of cures with this drug has been very high (Sylvestre, Gallai, and Ethier, 1959; Sylvestre and Gallai, 1960; Bouziane and Desranleau, 1960). However, such results were obtained by combined local and oral administration of Flagyl. Although numerous compounds have been tested against Trichomonas vaginalis infections in man, no specific drug had yet been found which would produce a cure when given orally alone. The final test of any drug in this persistent and recurring infection should be based on its effectiveness in systemic treatment. The present communication reports the findings of orally-administered Flagyl in cases of Trichomonas vaginalis vaginitis.

\section{Material and Methods}

Female patients attending the Urology Clinic of Jefferson Medical College Hospital were screened for trichomonal vaginitis and grouped according to type of infection. The presence of the flagellate was established by wet-film preparations of the vaginal discharge. The type of infection was diagnosed by the symptomatology and by inspection of the vulva and speculum examination of the vagina (Feo, 1960). In addition, Gram-stained smears of the vaginal discharge were prepared and the type of flora graded according to the classification of Schröder (1921).

Flagyl was given to 46 patients aged from 15 to 74

* Received for publication October 11, 1960. years, in whom the infection was classified as acute, chronic, or carrier-state (Table I). Among these were twelve patients with the classical symptoms and signs of an acute trichomonal vaginitis. Eighteen patients suffered from a chronic Trichomonas vaginalis vaginitis, and usually complained only of a persistent or intermittent vaginal discharge of unknown duration. Many in this group presented extra-vaginal foci of infection. The carrier-state was discovered in sixteen cases. Such patients were asymptomatic and presented minimal local signs in the presence of the flagellates.

TABLE I

TYPE OF TRICHOMONAS VAGINALIS INFECTIONS BY AGE GROUP

\begin{tabular}{|c|c|c|c|c|c|}
\hline \multirow{2}{*}{\multicolumn{3}{|c|}{ Age (yrs) }} & \multicolumn{3}{|c|}{ Infection } \\
\hline & & & \multirow{2}{*}{$\begin{array}{c}\text { Acute } \\
4\end{array}$} & \multirow{2}{*}{$\begin{array}{c}\text { Chronic } \\
0\end{array}$} & \multirow{2}{*}{$\begin{array}{c}\text { Carrier-state } \\
0\end{array}$} \\
\hline 10-19 & . & .. & & & \\
\hline $20-29$ & .. & .. & 3 & 2 & 3 \\
\hline $30-39$ & .. & .. & 3 & 4 & 5 \\
\hline $40-49$ & .. & .. & 2 & 5 & 1 \\
\hline $50-59$ & .. & $\ldots$ & 0 & 3 & 5 \\
\hline $60-69$ & .. & .. & 0 & 2 & 2 \\
\hline $70-79$ & .. & $\ldots$ & 0 & 2 & 0 \\
\hline & & .. & 12 & 18 & 16 \\
\hline
\end{tabular}

All patients investigated were ambulatory and were therefore not under strict supervision. However, all local manipulations, such as coitus, douching, and other medications, were prohibited during the period of oral therapy and observation.

Two 250-mg. tablets of SC-10295† or Flagyl + were prescribed twice daily for $\mathbf{1 0}$ days. Patients were asked to take two tablets on arising and two tablets on retiring. Each patient was then examined within 4 days of completion of the treatment, and those patients with negative smears were re-examined at weekly intervals for 3 weeks. The tests included wet-films, Gram-stained preparations, and cultures of the vaginal secretions. The criterion of cure, however, was the absence of the

† Laboratory designation for the compound.

$\ddagger$ Received through the courtesy of G. D. Searle and Company, 219 
organism in the cultures. The treated cases which remained negative for 3 weeks were considered to be cured of the infection. The reappearance of Trichomonas vaginalis within this 3 week interval was diagnosed as due to a recurrence of the infection, but if the flagellate reappeared after 3 weeks the case was classified as a re-infection.

\section{Results}

Out of the twelve patients with the acute infections, eleven completed satisfactory tests of cure after one course of Flagyl. The one failure was a 15-year-old girl who had been given a reduced dosage ( $250 \mathrm{mg}$. twice daily for 7 days) because of her age. However, she was cured by a dosage of $250 \mathrm{mg}$. three times daily for 7 days. Two patients were subsequently diagnosed as cases of re-infection; one was re-treated and cured by a second course, and the other was pregnant with a concomitant severe Candida albicans infection, and the treatment was directed to this complication.

Eighteen patients were suffering from a chronic trichomonas vaginitis, and seventeen of these were placed on full dosage. One patient defaulted and sixteen passed the tests of cure. The other, a 16-year-old patient, was cured by $750 \mathrm{mg}$. in three divided doses daily for 7 days.

Of the sixteen carrier cases, one defaulted and fifteen others were cured with the initial course of treatment. One patient was found to be reinfected 4 weeks later.

Of the 46 cases observed two defaulted. The results of treatment were assessed in the remaining 44 patients who satisfactorily completed the tests of cure established for this study. There were no relapses. Three patients were later (after 1-3 months) found positive for Trichomonas vaginalis and were classed as cases of re-infection.

In the acutely infected patients the immediate response to therapy was the rapid regression of symptoms. In general, however, the most striking effect was the suppression of activity with the disappearance of the organism and restoration of the normal vaginal secretion. A Grade I flora was established in 21 out of 27 patients with a Grade III flora. Of fourteen patients with a Grade II flora, nine showed Grade I after completion of the treatment schedule. Thus, 76 per cent. of the cases with a
Grade III and Grade II flora achieved Grade I with their initial treatment. Döderlein's bacillus was demonstrated in 98 per cent. of the treated patients studied by Gram-stained smears (Table II).

TABLE II

EFFECT OF THERAPY ON GRADE OF FLORA

\begin{tabular}{|c|c|c|c|c|c|c|c|c|}
\hline \multirow{3}{*}{$\begin{array}{c}\text { Type of } \\
\text { Infection }\end{array}$} & \multirow{3}{*}{$\begin{array}{l}\text { Total } \\
\text { No. of } \\
\text { Cases }\end{array}$} & \multirow{3}{*}{$\begin{array}{l}\text { No. } \\
\text { In- } \\
\text { cluded }\end{array}$} & \multicolumn{6}{|c|}{ Grade of Flora } \\
\hline & & & \multicolumn{3}{|c|}{$\begin{array}{c}\text { Before } \\
\text { Treatment }\end{array}$} & \multicolumn{3}{|c|}{$\begin{array}{c}\text { After } \\
\text { Treatment }\end{array}$} \\
\hline & & & I & II & III & I & II & III \\
\hline Acute & 12 & 12 & 0 & 0 & 12 & 9 & 3 & 0 \\
\hline Chronic .. & 18 & $17^{*}$ & 0 & 4 & 13 & 13 & 3 & 1 \\
\hline Carrier .. & 16 & $13 t$ & 1 & 10 & 2 & 9 & 4 & 0 \\
\hline
\end{tabular}

* One patient defaulted.

† One patient defaulted. No bacteria were seen on Gram-stained smears of two patients.

It is interesting to note that neither the age of the patients nor the results of previous pelvic surgery had any effect on the surprisingly high rate of cure. In this series there were six postmenopausal patients between the ages of 55 and 74 years, and nine patients in their menopause. Incidentally, three of the latter group volunteered the information that their symptoms and general well-being improved with the medication. Eleven of the observed patients had had hysterectomy performed, five with removal of the cervix.

Of the 44 treated patients who continued under detailed observation, twenty had not relapsed after 1 month. In follow-up periods of 2 to 9 months there were two re-infections among the other 23 patients.

Generally no intolerance to Flagyl was observed. Two patients noted indigestion and one a bitter taste in the month during the course of therapy. Two other women described a sensation of 'tightness' or dryness in the vagina. In those who did complain, the side-effects were mild, and no course had to be interrupted or abandoned on this account.

\section{Discussion}

Many drugs will symptomatically relieve and so temporarily "cure" patients suffering from trichomonal vaginitis. In many of the reported studies the cure-rate has been high. It is appreciated, however, 
that these figures are not reliable because the incidence of recurrences is also high. This does not mean that such drugs are not potent, but rather indicates that locally-applied medication has not reached the hidden reservoirs of infection. In view of this, attention has been focused, in recent years, on the systemic treatment of trichomoniasis. Recently nine British clinicians reported their clinical experience with Flagyl given by the oral route only (M.S.S.V.D. 1960). The immediate successrate in the female group was 86 per cent. or better. This communication prompted the publication of the present study. If only those patients completing satisfactory tests of cure in this series are considered, the cure rate is 44 out of 44 . While there is no strictly comparable series available of cases treated by oral administration alone, there is no doubt that better results could hardly be imagined. This conclusion is drawn, in spite of the small number of patients, through knowledge of the inefficacy of the earlier oral remedies.

No doubt the observation period of 3 weeks may be questioned by some. Unfortunately, it is axiomatic that as the period of symptomatic relief lengthens, the problem of re-infection becomes more manifest. Notwithstanding this contingency, 52 per cent. of the treated patients showed a duration of cure of 2 to 9 months while under observation.

The results of this therapeutic trial have shown the effectiveness of an orally-administered drug in clearing Trichomonas vaginalis from the vagina. These findings are also remarkable for the absence of relapses. An interesting observation is that this excellent cure rate was affected neither by the age of the patient nor, apparently, by the anatomical or physiological state of the vagina.

The observations are still too limited in number to allow precise evaluation of the mode of action of this compound. Nevertheless, the first impression is that of the remarkable action of the drug on the vaginal mucosa as reflected by the cellular contents of the secretions. That the compound acts directly on the vagina or positively on the flagellate cannot be assessed clinically. A second impression, arising from the improved well-being of some of the menopausal patients, favours a central action of the drug followed by an indirect effect on the physiology of the vagina. These questions are under current investigation. Suffice it to say that this oral medication appears to be a specific and practical treatment for Trichomonas vaginalis vaginitis.

\section{Summary}

(1) At the Jefferson Medical College Hospital, Philadelphia, 46 patients suffering from trichomonal vaginitis were treated. Two defaulted, and 44 were followed-up under established conditions.

(2) 42 patients received Flagyl in an oral dose of $500 \mathrm{mg}$. twice daily for 10 days. The other two received $750 \mathrm{mg}$. in three divided doses daily for 7 days.

(3) The following tests of cure were carried out in all cases:

(i) Wet-films and Gram-stained preparations of the vaginal secretions.

(ii) Cases with smears negative for Trichomonas vaginalis were re-examined at weekly intervals for 3 weeks.

(iii) The criterion for cure was the absence of the flagellate from cultures.

(4) Of the 44 treated patients who completed tests of cure, all passed, with no relapses. Of those patients who proved negative for Trichomonas vaginalis, 21 continued under observation for 1 month and one became re-infected. In follow-up periods of 2 to 9 months, there were two re-infections among the other 23 cases.

(5) It is suggested that the success rate of Flagyl represents a high standard of efficacy. Furthermore, this drug possesses the great virtue of producing results by an oral course of ambulatory treatment.

\section{REFERENCES}

Bouziane, N. R., and Desranleau, J. M. (1960). Union méd. Canada, 89, 759.

Cosar, C., and Julou, L. (1959). Ann. Inst. Pasteur, 96, 238.

Durel, P., Roiron, V., Siboulet, A., and Borel, L. J. (1959). C.R. Soc. franç. Gynéc., $29,36$.

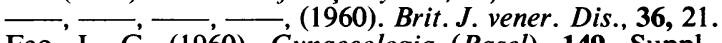
Feo, L. G. (1960). Gynaecologia (Basel), 149, Suppl., p. 101.

Fortier, L. (1960). Ibid., p. 158.

Horie, H. (1956). J. Antibiot., Ser. A, 168.

M.S.S.V.D. (1960). Lancet, 1, 1226.

Nakamura, S. (1955). Pharm. Bull. (Jap.), 3, 379.

Schröder, R. (1921). Zbl. Gynäk., 45, 1350.

Sylvestre, L., Gallai, Z., and Ethier, J. (1959). Urol. int. (Basel), 9, 356.

- _- (1960). Un. méd. Canada, 89, 735.

\section{Le Flagyl dans le traitement oral de la vaginite à trichomonas}

\section{Résumé}

(1) A l'Hôpital de l'École de Médecine Jefferson, Philadelphie, l'auteur traita 46 cas de vaginite à trichomonas. Deux femmes abandonnèrent le traitement et 44 furent suivies d'une façon déterminée.

(2) 42 malades reçurent par la bouche une dose de $500 \mathrm{mg}$. de Flagyl deux fois par jour pendant 10 jours.

(n)


Les deux autres reçurent trois doses de $250 \mathrm{mg}$. par jour pendant 7 jours.

(3) L'auteur procéda dans tous les cas aux tests suivants:

(i) Films humides et préparations, colorées par la méthode de Gram, des sécrétions vaginales.

(ii) Quand les frottis étaient négatifs pour le Trichomonas vaginalis, la malade était examinée tous les huit jours pendant 3 semaines.

(iii) le critère de la guérison était l'absence de flagellés dans les cultures.

(4) Il n'y eut pas une seule récurrence chez les 44 malades qui furent soumises aux tests ci-dessus. parmi les malades dont les frottis furent négatifs pour le Trichomonas vaginalis, 21 furent suivies pendant un mois et une fut réinfectée. Pendant la période de surveillance, qui varia de 2 à 9 mois, il y eut deux réinfections parmi les 23 autres cas.

(5) L'auteur suggère que le taux élevé des guérisons obtenues par le Flagyl souligne l'efficacité de ce produit. En outre, ce médicament présente l'avantage d'être administré par la bouche et de permettre un traitement ambulatoire. 